SISTEMA
ELETRONICO
DE REVISTAS
SER I UfPR

\title{
Análise dos crimes ambientais registrados nas regiões do Baixo Amazonas e Tapajós, Pará, no período de 2012 a 2015
}

\section{Analysis of environmental crimes in the Baixo Amazonas and Tapajós regions, Pará, from 2012 to 2015}

\author{
Áurea Siqueira de Castro AZEVÊDO ${ }^{1 *}$, Thiago Almeida VIEIRA ${ }^{1}$ \\ ${ }^{1}$ Programa de Pós-graduação em Sociedade, Ambiente e Qualidade de Vida, Universidade Federal do Oeste do Pará (UFOPA), Santarém, PA, Brasil. \\ *E-mail de contato: aureacastro_stm@yahoo.com.br
}

Artigo recebido em 11 de agosto de 2017, versão final aceita em 10 de maio de 2018.

RESUMO: $\quad$ Previstos na Lei Federal n 9.605/1998, a Lei de Crimes Ambientais-LCA, ou em outra norma esparsa, os crimes ambientais são atos ilícitos que provocam resultado danoso ao meio ambiente. O objetivo deste estudo foi diagnosticar e analisar as infrações ambientais cometidas em 19 municípios das regiões do Baixo Amazonas e Tapajós, no Estado do Pará, registradas no período de 2012 a 2015, pela Secretaria de Estado de Meio Ambiente e Sustentabilidade (SEMAS). Foram realizadas pesquisas bibliográfica e documental nos autos de infração de 598 processos formalizados pelo órgão de fiscalização ambiental estadual, cujos dados foram agrupados nas cinco categorias de crimes ambientais previstas na LCA e em uma categoria para os crimes previstos em outras leis. Dos processos analisados, 69\% versavam sobre infrações contra a flora, com maior ocorrência nos municípios de Santarém, Monte Alegre e Novo Progresso. O desmatamento/destruição da vegetação foi a tipologia infracional mais cometida contra a flora, especialmente em Santarém, Monte Alegre e Prainha. Dos demais processos, 11\% versavam sobre crimes de poluição, $10 \%$ sobre crimes contra a administração ambiental, $6 \%$ sobre crimes previstos em outras leis e 4\% sobre crimes contra a fauna, não sendo verificados crimes contra o ordenamento urbano e o patrimônio cultural. Santarém foi o município que liderou o quantitativo de crimes em 4 categorias. Conclui-se que o desmatamento, incitado pela potencialização dos interesses privados da exploração dos recursos, indica para onde devem ser convergidos os esforços do Poder Público para a sensibilização e disciplina da sociedade.

Palavras-chave: Amazônia; desmatamento; flora; infração; poluição.

ABSTRACT: Under Brazilian Federal Law 9605/1998, the Law of Environmental Crimes-LEC, or in another sparse norm, environmental crimes are illegal acts that cause harmful results to the environment. The objective of this study was to diagnose and analyze the environmental infractions committed in 19 municipalities of the regions of Baixo Amazonas and Tapajós, in the state of Pará, registered in the period from 2012 to 2015 by the State 
Secretariat of Environment and Sustainability - SEMAS. Bibliographical and documentary research was carried out in the infraction notices of 598 cases formalized by the state environmental oversight body, whose data were grouped into the five categories of environmental crimes set forth by the LEC and in a category for crimes under other laws. Among the analyzed processes, $69 \%$ were about infractions against the flora, with greater occurrence in the municipalities of Santarém, Monte Alegre and Novo Progresso. The deforestation / destruction of vegetation was the most common infraction typology against the flora, especially in Santarém, Monte Alegre and Prainha. Of the other cases, $11 \%$ concerned pollution offenses, $10 \%$ on crimes against environmental administration, $6 \%$ on crimes foreseen in other laws and $4 \%$ on crimes against fauna, and no crimes against urban planning and cultural heritage were verified. Santarém was the municipality that led the number of crimes in 04 categories. It is concluded that deforestation, prompted by the enhancement of the private interests of the exploitation of resources, indicates where the efforts of public power for the sensitization and discipline of society should converge.

Keywords: Amazon; deforestation; flora; infraction; pollution.

\section{Introdução}

A proteção do meio ambiente é uma regra constitucional disposta no art. 225 da Carta Magna de 1988, o qual determina que "Todos têm direito ao meio ambiente ecologicamente equilibrado, bem de uso comum do povo e essencial à sadia qualidade de vida, impondo-se ao Poder Público e à coletividade o dever de defendê-lo e preservá-lo para às presentes e futuras gerações" (Brasil, 1988). À medida, então, em que cresce a degradação do meio ambiente, afetando de forma negativa a qualidade de vida das pessoas e colocando em risco as futuras gerações, torna-se crucial a maior e eficaz tutela dos recursos ambientais pelo Poder Público e por toda a coletividade (Amado, 2014).

Neste sentido, um dos instrumentos utilizados pelo Poder Público visando à proteção do meio ambiente é a prática do poder de polícia administrativa - o que, segundo Milaré (2011), é exercido mais comumente por meio de ações fiscalizatórias. Trata-se de um importante instrumento para a constatação dos crimes ambientais. Estes crimes, conforme Copola (2012), são todos os atos ilícitos que provocam resultado danoso ao meio ambiente. Eles devem estar previstos na Lei ${ }^{\circ} 9.605$, de 12 de fevereiro de 1998, conhecida como Lei de Crimes Ambientais - LCA, ou em outra norma esparsa.

De acordo com Santilli (2007), a LCAé o principal instrumento voltado para a responsabilização criminal dos danos causados ao meio ambiente. Esse dispositivo prevê crimes contra a flora, fauna, ordenamento urbano, patrimônio cultural, administração ambiental e os crimes de poluição, além das sanções administrativas aplicáveis às condutas lesivas ao meio ambiente. Para Tedardi (2009), a imposição e implementação de medidas de cunho administrativo, civil e penal, com o fim de coibir as agressões causadas ao meio ambiente, é plenamente justificável, uma vez que o direito de viver em um ambiente ecologicamente equilibrado é garantido constitucionalmente.

No bojo das discussões acerca da proteção ambiental, a Amazônia tem importante destaque por representar o maior bioma de floresta úmida do mundo e abrigar inúmeras espécies naturais. A partir de 1960, a região passou por políticas de coloniza- 
ção e pelo desenvolvimento de diferentes programas e projetos instituídos pelo governo federal, a exemplo do Plano de Integração Nacional (PIN), II Plano Nacional de Desenvolvimento, Programa de Pólos Agropecuários e Agrominerais da Amazônia (Polamazônia) e Programa Grande Carajás. Os objetivos destas ações incluíram desde a ocupação e integração da área até sua efetiva participação na economia nacional, aliados, ainda, à criação de uma infraestrutura capaz de suportar o desenvolvimento previsto para a região. Estas práticas, além de modificar o dinamismo interno do território, também geraram maior pressão sobre os recursos ambientais amazônicos (Dalgo \& Suhett, 2009).

Localizada no Estado do Pará, a região do Baixo Amazonas vivenciou tais intervenções estatais. Em termos de integração, houve a implementação de políticas de migração induzida e instalação de redes energéticas, de telecomunicações e viárias, a exemplo da BR-163 (Cuiabá-Santarém) e da BR222 (Transamazônica). Em termos de desenvolvimento, destacam-se os incentivos e isenções fiscais para atração da indústria agropecuária e mineral e as grandes obras de infraestrutura, como a construção de portos. Foi criado, então, o suporte necessário para a expansão da fronteira agropecuária e, posteriormente, a expansão da produção de grãos e a produção mineral, a partir da instalação de grandes empresas minero-metalúrgicas em diferentes pontos da região (Costa, 2015a).

A mesma lógica de ocupação e desenvolvimento também ocorreu na região do Tapajós, Pará. Segundo Costa (2011), esta porção do território paraense é marcada pela pecuária e agricultura, atividades que foram impulsionadas pela construção da BR-163 e pelo modo de colonização adotado. Além disso, a região do Tapajós também é caracteri- zada pela atividade minerária e extração madeireira. Desta forma, em ambas as regiões, o dinamismo do uso do território tem provocado intensa pressão sobre os recursos ambientais locais. Isso torna essas áreas passíveis à ocorrência de práticas lesivas ao meio ambiente, o que reforça a necessidade de maior controle e combate aos ilícitos ambientais.

Neste sentido, considerando a preocupação e a necessidade de garantir o uso sustentável dos recursos ambientais na Amazônia, torna-se relevante uma análise dos crimes ambientais registrados nas regiões do Baixo Amazonas e Tapajós, no Estado do Pará. A partir do conhecimento dos crimes mais ocorrentes nestas regiões, pode ser possível delinear políticas públicas e estratégias de sensibilização ambiental e combate aos crimes cometidos. Isso favoreceria a proteção e conservação do meio ambiente.

Com isso em consideração, o objetivo deste estudo consistiu em diagnosticar e analisar as infrações ambientais cometidas nas regiões do Baixo Amazonas e Tapajós no Estado do Pará. Os casos foram registrados no período de 2012 a 2015, pela Secretaria de Estado de Meio Ambiente e Sustentabilidade (SEMAS). A análise visa a apontar os tipos de infrações ambientais mais ocorrentes em tais regiões e identificar os municípios que apresentaram maior pressão sobre os recursos ambientais.

\section{Metodologia}

O estudo teve caráter descritivo, envolvendo uma investigação sobre o tema proposto por meio de uma pesquisa bibliográfica e documental. Foram estudadas ocorrências de crimes ambientais em 19 municípios paraenses, sendo 13 da região do Baixo 
Amazonas (Alenquer, Almeirim, Belterra, Curuá, Faro, Juruti, Monte Alegre, Mojuí dos Campos, Óbidos, Oriximiná, Prainha, Terra Santa e Santarém) e 6 da região do Tapajós (Aveiro, Itaituba, Jacareacanga, Novo Progresso, Rurópolis e Trairão), de acordo com a divisão adotada pela SEMAS para o exercício de sua competência, de forma regionalizada (Figura 1). A escolha por tais regiões se deve à existência de um Núcleo Regional do órgão em Santarém e que atende às regiões e municípios citados. A coleta de dados foi realizada neste núcleo.

A base de dados utilizada para a coleta de informações sobre os crimes ambientais consistiu nos autos de infração lavrados pela SEMAS, no período de 2012 a 2015. Para tanto, foram consideradas informações sobre a data de abertura do processo punitivo no órgão. Por meio do sistema virtual interno, manuseado por um servidor da regional, foi constatado o número de processos instaurados pela SEMAS no período e regiões estudados. Destes, foram excluídos os processos punitivos protocolados e não tramitados virtualmente, uma vez que tal fato indica a geração de dois números de processos à mesma infração. Aferiu-se, então, a abertura de 764 processos punitivos.

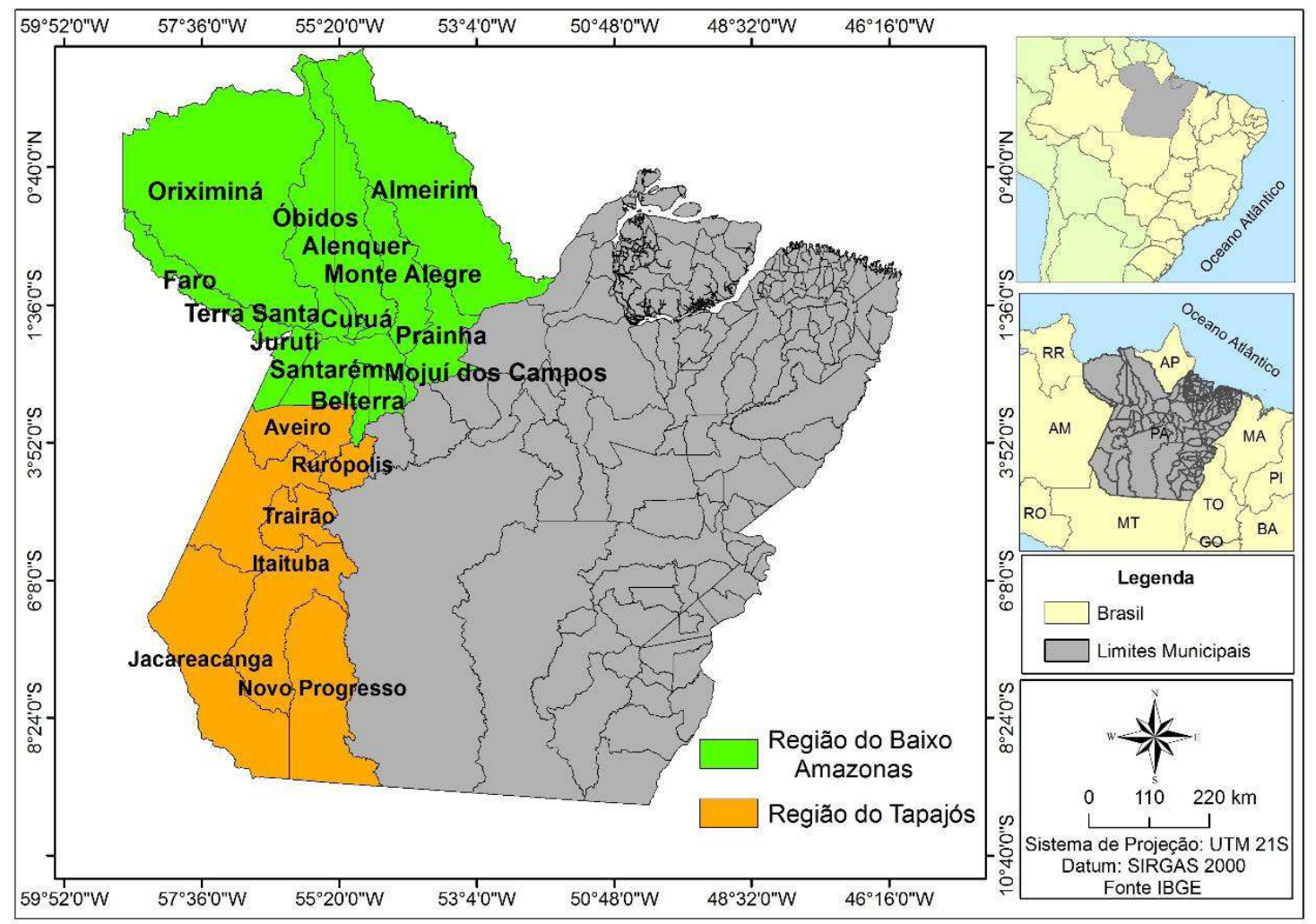

FIGURA 1 - Localização dos municípios das regiões do Baixo Amazonas e Tapajós, Pará. 
No entanto, é importante destacar que a instauração, bem como a análise jurídica desses processos, pode ocorrer tanto na regional em Santarém, quanto na sede em Belém. Isso porque a fiscalização nas regiões pesquisadas é realizada por fiscais lotados nas bases destes municípios. Como consequência, o processo geralmente é formalizado e analisado na base administrativa a qual o fiscal é lotado, o que leva à existência de dois locais de concentração de processos punitivos. Desta forma, não foi possível averiguar a totalidade de processos abertos no período estudado, especialmente dos que se encontravam em Belém, ainda que alguns tenham sido verificados com o apoio do Núcleo Regional de Santarém, por meio de informações constantes no sistema virtual interno. Os processos que se encontravam na regional do órgão ambiental foram verificados documentalmente.

Foram colhidas informações do município em que a infração ocorreu e o ano de abertura do processo, além da ação cometida que tipificou o crime, em processos punitivos e autos de infração que foram analisados, de fato, tanto virtual quanto fisicamente. De forma a subsidiar a categorização e análise dos dados, também foram verificados os artigos da legislação ambiental nos quais a infração foi enquadrada pelos fiscais ambientais.

Os registros coletados sobre as infrações foram agrupados nas cinco categorias de crimes previstas na Lei de Crimes Ambientais. São elas: 1) contra a fauna; 2) contra a flora; 3) poluição e outros crimes; 4) contra o ordenamento urbano e o patrimônio cultural; e 5) contra a administração ambiental, ainda que o crime ambiental tenha sido apurado com base no decreto regulamentador da referida lei. Além disso, os crimes constatados pelo órgão ambiental estadual e que não têm previsão específica na Lei de Crimes Ambientais e/ou seu decreto regulamentador foram agrupados na categoria denominada "crimes previstos em outros dispositivos legais".

Depois desta etapa, os dados obtidos foram tabulados e interpretados qualitativamente, de forma a indicar quantitativamente o comportamento das variáveis no período de estudo. Foi usada a estatística descritiva para a análise das informações.

\section{Resultados e discussão}

\subsection{Quantificação das infrações}

De 764 processos punitivos formalizados pela SEMAS no período de 2012 a 2015, foram analisados 598 autos de infração, o equivalente a $78 \%$ dos casos. A Tabela 1 apresenta a totalidade de processos punitivos existentes no órgão ambiental estadual e o quantitativo efetivamente analisado por município.

Os municípios que apresentaram maior número de processos punitivos instaurados foram Santarém $(n=162)$, Itaituba $(n=110)$, Novo Progresso $(n=108)$, Monte Alegre $(n=84)$, Prainha $(n=68)$ e Trairão $(\mathrm{n}=53)$. Eles ocupam, respectivamente, o $1^{\circ}, 2^{\circ}, 11^{\circ}, 4^{\circ}, 10^{\circ}$ e $12^{\circ}$ lugares em número de habitantes, considerando os dados de julho de 2015 do Instituto Brasileiro de Geografia e Estatística (IBGE, 2015a).

Acredita-se que a existência do Núcleo Regional da SEMAS em Santarém tenha contribuído para o elevado número de processos neste município em relação aos demais, já que, além de favorecer o recebimento de denúncias de crimes, o deslocamento até a área a ser fiscalizada é facilitado e os custos da ação (deslocamento e diárias) são reduzidos. Essas são as vantagens da desconcentração da gestão am- 
biental, estratégia em que, segundo Motta \& Pêgo (2013), há a transferência de algumas atividades dos escritórios centrais para unidades regionalizadas no âmbito da mesma pessoa jurídica, como é o caso do órgão ambiental do Estado do Pará. A desconcentração, conforme os autores, permite agilizar e viabilizar o processo de licenciamento e outras demandas em determinados polos, uma vez que o Estado passa a se fazer mais presente em municípios muitas vezes longínquos da capital.

TABELA 1 - Quantitativo de processos punitivos existentes no órgão ambiental estadual, número e percentual de processos analisados por município, no período de 2012 a 2015, nas regiões Baixo Amazonas e Tapajós, Pará.

\begin{tabular}{|c|c|c|c|}
\hline Município & Total & Analisados & $\operatorname{Fr}(\%)$ \\
\hline Alenquer & 16 & 13 & 81 \\
\hline Almeirim & 25 & 16 & 64 \\
\hline Aveiro & 26 & 21 & 81 \\
\hline Belterra & 14 & 12 & 86 \\
\hline Curuá & 5 & 5 & 100 \\
\hline Faro & 1 & 1 & 100 \\
\hline Itaituba & 110 & 65 & 59 \\
\hline Jacareacanga & 7 & 7 & 100 \\
\hline Juruti & 10 & 9 & 90 \\
\hline Mojuí dos Campos & 6 & 4 & 67 \\
\hline Monte Alegre & 84 & 74 & 88 \\
\hline Novo Progresso & 108 & 69 & 64 \\
\hline Óbidos & 23 & 21 & 91 \\
\hline Oriximiná & 10 & 7 & 70 \\
\hline Prainha & 68 & 61 & 90 \\
\hline Rurópolis & 32 & 24 & 75 \\
\hline Santarém & 162 & 140 & 86 \\
\hline Terra Santa & 4 & 3 & 75 \\
\hline Trairão & 53 & 46 & 87 \\
\hline TOTAL & 764 & 598 & 78 \\
\hline
\end{tabular}

Fr (\%): percentual de processos analisados em relação ao total por município.
Ao se comparar as regiões, nota-se que a do Baixo Amazonas foi a que apresentou maior quantidade de registro de crime ambiental, com 428 registros, enquanto a região do Tapajós, 336 registros. Uma possível explicação para isso é o maior número de municípios inseridos na região do Baixo Amazonas, que reúne 13 municípios e uma área de $315.852,94 \mathrm{~km}^{2}$. A região do Tapajós, por outro lado, envolve 6 municípios e uma área de 189.595,10 $\mathrm{km}^{2}$ (IBGE, 2015b). O quantitativo populacional também pode representar uma possível explicação para o elevado número de infrações na região, visto que o Baixo Amazonas possui 710.861 habitantes. Já o Tapajós, 214.099 habitantes. Somente Santarém possui 292.520 habitantes (IBGE, 2015a), ou seja, número superior à população da região do Tapajós, o que o reforça como município com o maior número de registro de crimes ambientais nas áreas estudadas.

\subsection{Período e categorias de crimes}

Considerando a totalidade de 764 processos punitivos existentes no órgão ambiental estadual, no ano de 2012 foram instaurados 126 processos. Houve um acréscimo em 2013 e redução no ano de 2014, seguida de uma duplicação em 2015, quando foram formalizados 314 processos. Observa-se a mesma tendência junto aos 598 processos punitivos que, de fato, foram analisados (Figura 2).

O maior número de processos punitivos abertos em 2015 pode ser explicado pelo esquema de fiscalização adotado nesse período. Quando há operações fiscalizatórias para averiguar um crime ambiental específico, a exemplo do desmatamento, são mobilizadas várias equipes de maneira simultânea 
para o desenvolvimento da ação. Assim, maiores são as possibilidades de se constatar crimes e, por conseguinte, lavrar autos de infração, se comparadas com ações de fiscalização que ocorrem de maneira pontual e esparsa, sem emprego de grande número de pessoal, incluindo os fiscais ambientais.

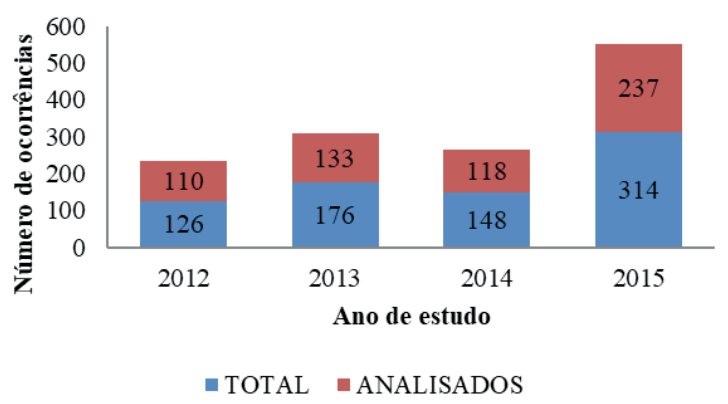

FIGURA2 - Número total de processos punitivos existentes na SEMAS e número de processos analisados por ano de estudo, nas regiões do Baixo Amazonas e Tapajós, Pará.

Ademais, é importante considerar que a fiscalização nas regiões de abrangência pode ser realizada por qualquer agente de fiscalização ambiental estadual legalmente nomeado para este fim. Dessa forma, depreende-se que, nesse período, houve maior atuação de equipes de fiscalização da sede do órgão em Belém nas regiões do Baixo Amazonas e Tapajós, visto que o Núcleo Regional de Santarém dispunha de apenas 1 fiscal para atender as citadas regiões.

Dos 598 processos punitivos analisados, 69\% versavam sobre infrações cometidas contra a flora $(n=411)$. Essa foi a principal categoria de crimes cometidos nas regiões em estudo. Dos demais processos, $11 \%(n=69)$ versavam sobre crimes de poluição, $10 \%(n=63)$ sobre crimes contra a administração ambiental e $6 \%(n=34)$ sobre crimes previstos em outros dispositivos legais. Os crimes contra a fauna foram os que apresentaram menor percentual de registro, perfazendo apenas $4 \%(n=21)$ dos casos analisados (Figura 3).

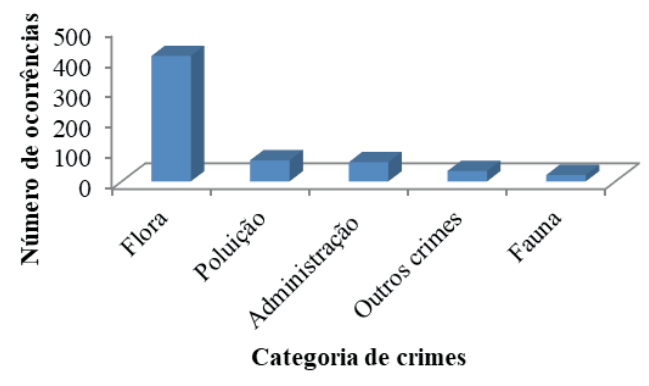

FIGURA 3 - Número de infrações ambientais por categoria, registradas pela SEMAS no período de 2012 a 2015, nas regiões do Baixo Amazonas e Tapajós, Pará.

É importante destacar que, no período de estudo, não foram verificados registros de crimes contra o ordenamento urbano e o patrimônio cultural, embora ações de pichações, um dos ilícitos previstos nesta categoria na LCA, sejam frequentes nas zonas urbanas. Além disso, ainda que existam variadas edificações históricas situadas em logradouros públicos - especialmente na região do Baixo Amazonas, cujas cidades foram alvo da colonização portuguesa -, poucos imóveis são protegidos por algum ato legal, administrativo ou judicial. De acordo com a lista de bens materiais tombados pelo Instituto do Patrimônio Histórico e Artístico Nacional - IPHAN (2015), por exemplo, apenas os municípios de Aveiro, Belterra, Óbidos e Oriximiná têm bens que se encontram com processo de tombamento em andamento. 
Os resultados apresentados pelas regiões paraenses estudadas seguem, parcialmente, a tendência brasileira de registros de crimes averiguados pelo Instituto Brasileiro do Meio Ambiente e dos Recursos Naturais Renováveis (IBAMA) e pelos órgãos ambientais estaduais. Isso porque, considerando Uhr \& Uhr (2014), a média de crimes contra a flora nos estados brasileiros é muito maior do que a média para as demais categorias. Essa situação se configura como a principal categoria de autuação no país, tanto em quantidade quanto em importância socioambiental, com destaque para a região Norte do Brasil. Ainda assim, em razão da quantidade de autos lavrados, Uhr \& Uhr (2014) apontam os crimes contra a fauna como a segunda categoria mais representativa dos crimes ambientais, o que não é observado no presente estudo.

Considerando a categoria dos crimes ambientais dos 598 processos analisados em relação ao ano do fato ilícito, observa-se que o maior quantitativo de infrações contra a flora e fauna - com 198 e 12 registros, respectivamente - foi registrado em 2015. Este também foi o ano de maior ocorrência de crimes totais, conforme a Tabela 2. Por outro lado, os crimes contra a administração ambiental apresentaram maior registro $(n=21)$ em 2014, ano com a segunda menor instauração de processos punitivos no órgão ambiental estadual. Já os crimes de poluição ambiental e os previstos em outros dispositivos legais apresentaram maior incidência no ano de 2013, com 33 e 17 registros, respectivamente (Tabela 2 ).

\subsubsection{Crimes contra a flora}

Foram registradas 411 infrações contra a flora no período de estudo. Considerando essa totalidade, observa-se que a maioria das situações ocorreu nos municípios de Santarém ( $\mathrm{n}=81)$, Monte Alegre $(n=60)$ e Novo Progresso $(n=60)$. Os menores quantitativos foram registrados nos municípios de Mojuí dos Campos $(n=2)$, Terra Santa $(n=2)$, Faro $(n=1)$ e Oriximiná ( $n=1)$ (Figura 4). Desta forma, todos os

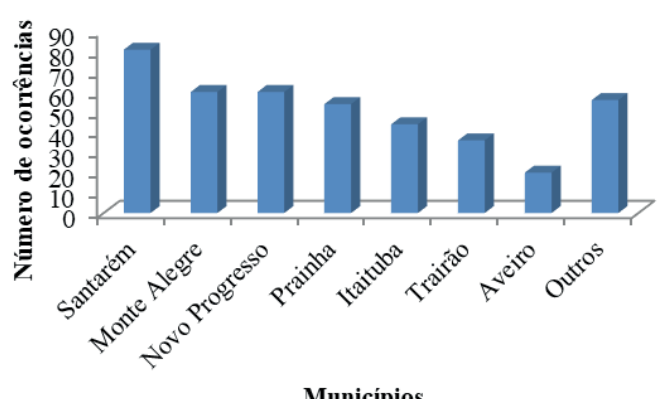

FIGURA 4 - Número de infrações contra a flora por município, registradas no período de 2012 a 2015, nas regiões do Baixo Amazonas e Tapajós, Pará.

TABELA 2 - Número de crimes ambientais analisados por categoria no período de 2012 a 2015, nas regiões Baixo Amazonas e Tapajós, Pará.

\begin{tabular}{|c|c|c|c|c|c|}
\hline Categoria de Crimes Ambientais & 2012 & 2013 & 2014 & 2015 & TOTAL \\
\hline Flora & 86 & 65 & 62 & 198 & 411 \\
\hline Administração ambiental & 7 & 17 & 21 & 18 & 63 \\
\hline Crimes em outros dispositivos legais & 2 & 17 & 12 & 3 & 34 \\
\hline TOTAL & 110 & 133 & 118 & 237 & G 598 \\
\hline
\end{tabular}


19 municípios estudados apresentaram, ao menos, um registro de crime contra a flora.

Das 411 infrações ambientais contra a flora, o desmatamento/destruição da vegetação figurou como a tipologia infracional mais cometida. Neste sentido, 27\% $(\mathrm{n}=112)$ do total de crimes de desmatamento ocorreram em área de Reserva Legal (RL). Outros $23 \%(\mathrm{n}=95)$ foram em floresta, objeto especial de proteção. Esse enquadramento sobre florestas considera as propriedades onde não há definição de utilização de suas áreas, já que não possuem Cadastro Ambiental Rural (CAR) e/ou áreas florestadas cujo crime fora constatado em sobrevôo. Os demais registros correspondem a situações ocor- ridas em Área de Preservação Permanente (APP) -16\% ( $\mathrm{n}=66$ ) - e em Área de Uso Alternativo do Solo (AUAS), com 11\% ( $n=47)$. Juntas, tais infrações representam 78\% $(\mathrm{n}=320)$ do total de infrações cometidas contra a flora (Figura 5). O ano de 2015 foi o que apresentou maior número de registros para tais tipologias, com 198 registros, perfazendo $48 \%$ das ocorrências totais contra a flora.

Embora os resultados tenham revelado baixo número de registro de crimes cometidos em Unidades de Conservação, nota-se que o desmatamento atinge, principalmente, áreas protegidas, como RL e APP. Além de indicar desrespeito às normativas ambientais vigentes, a ação delituosa afeta a fun-

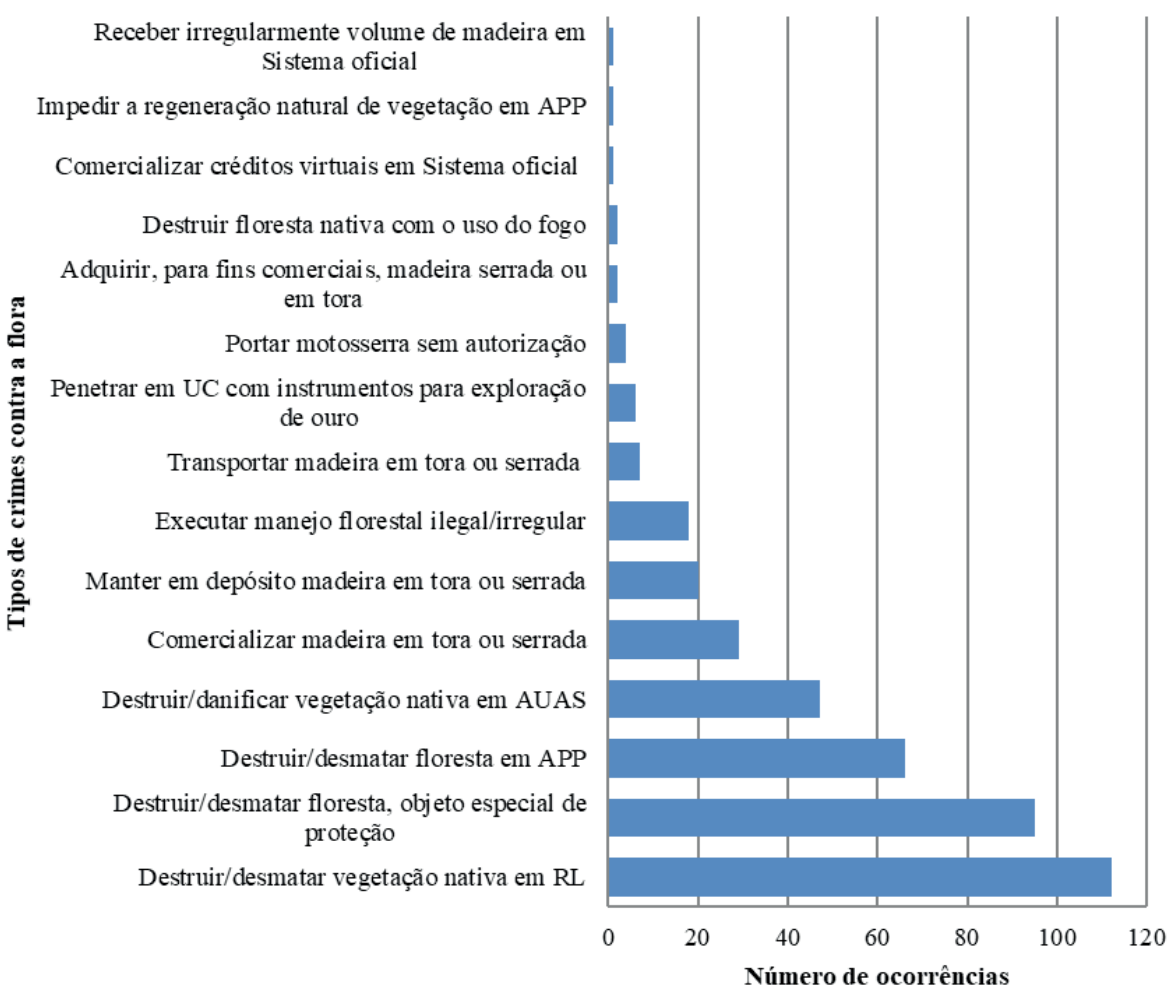

FIGURA 5 - Número e tipologias infracionais registradas contra a flora, no período de 2012 a 2015, nas regiões do Baixo Amazonas e Tapajós, Pará. 
cionalidade ambiental e sustentável intrínseca a tais áreas. Isso, por conseguinte, impacta o bem-estar das populações humanas. Conforme descreve a Lei $n^{\circ}$ 12.651/2012- Código Florestal Brasileiro, a intervenção ou a supressão de vegetação nativa em APP somente é possível em casos de utilidade pública, de interesse social ou de atividades de baixo impacto ambiental. Também somente é admitida exploração econômica da RL mediante manejo sustentável e a coleta de produtos florestais não madeireiros, sendo obrigatória a suspensão de atividades nestas áreas desmatadas irregularmente após 22 de julho de 2008.

Os quatro tipos de infração mais cometidos contra a flora ocorreram principalmente nos municípios de Santarém $(n=58)$, Monte Alegre $(n=57)$ e Prainha ( $\mathrm{n}=48)$, inseridos na região do Baixo Amazonas, e Novo Progresso ( $n=41)$, Itaituba $(n=33)$ e Trairão $(n=27)$, pertencentes ao Tapajós. Dos 19 municípios estudados, Curuá, Faro, Jacareacanga, Juruti e Oriximiná não apresentaram registros de infrações por desmatamento/destruição de vegetação. Ao se considerar apenas crimes cometidos em área de Reserva Legal, dos 112 registros, 31 (28\%) ocorreram em Santarém.

O desmatamento também foi a principal tipologia de crime registrada contra a flora no Estado do Amazonas nos anos de 2009 e 2010, correspondendo a $78 \%$ dos crimes, segundo o estudo de Fonseca et al. (2013). Igualmente, no município acreano de Cruzeiro do Sul, Ortega et al. (2012) revelaram que o desmatamento/queimada representou $55 \%$ do total de autos de infração lavrados contra a flora, de 2003 a 2010.

No caso do Pará, o elevado número de autos de infração lavrados por desmatamento, se comparado às demais tipologias infracionais contra a flora, pode ser justificado pelo modo de monitoramento ambiental adotado. Alertas de desmatamento do Instituto Nacional de Pesquisas Espaciais (INPE) e do Instituto do Homem e do Meio Ambiente da Amazônia (IMAZON) são enviados à SEMAS, norteando, assim, as atividades de fiscalização no Estado. Quando necessárias, também são estabelecidas parcerias com outros órgãos, a exemplo do IBAMA e Polícia Civil, que viabilizam a logística por meio da disponibilização de aeronaves para atender procedimentos fiscalizatórios. Ademais, no período estudado, a Gerência de Monitoramento Ambiental (GEMAM), da Diretoria de Fiscalização Ambiental (DIFISC), era o setor que identificava os focos de desmatamento nas análises dos processos de licenciamento em trâmite no órgão. A partir disso, essa gerência subsidiava o planejamento das ações de fiscalização.

A literatura aponta várias causas para o desmatamento na Amazônia. O problema é reflexo de uma série de eventos que se intensificaram nas últimas décadas do século XX: modelo de colonização amazônica, conflitos fundiários, crescimento da agropecuária, exploração madeireira, a abertura de estradas e a pavimentação de rodovias, dentre outros (Reydon, 2011; Munhoz, 2011; Schmitt, 2015). Para Costa (2011), a pecuária é o principal responsável pelo desflorestamento na região do Baixo Amazonas. A área apresenta três municípios que lideraram a lista das localidades com maior lavratura de autos relacionados ao desmatamento: Santarém, Monte Alegre e Prainha.

Segundo Simoni et al. (2012), é preciso considerar, no entanto, que o território do Baixo Amazonas se tornou uma forte fronteira de expansão agrícola nos últimos anos. Neste sentido, a possibilidade de pavimentação da rodovia BR-163 
tem motivado o crescimento de cultivos de arroz e soja, bem como o aumento da extração ilegal de madeira, resultando, dentre outras consequências, no aumento da desfragmentação florestal. Além disso, Costa (2015b) associa o grande estoque de terras, comercializadas a preços bastante inferiores aos praticados em regiões de plantação já consolidadas, à rápida expansão das lavouras, especialmente de soja.

Na identificação do crime ambiental e responsabilização dos infratores pela fiscalização estadual é considerado todo o polígono do desmatamento. Quanto maior seu tamanho, mais propriedades podem ser abarcadas, o que gera maior lavratura de autos de infração. Entretanto, conforme Costa (2011), os polígonos de desmatamento no Baixo Amazonas são menores, concentrados e exercidos por pequenos posseiros rurais. Ocorre, porém, que o somatório geral desses polígonos ocasiona uma grande área desmatada.

Além disso, Costa (2011) explica que o controle do desflorestamento nessa região é mais fácil devido à possibilidade de identificação dos posseiros e proprietários, fazendo com que sejam responsabilizados pelo crime ambiental cometido. Ao contrário, na região do Tapajós, embora os polígonos de desmatamento sejam maiores, a identificação do crime é dificultada pela pulverização dessas áreas. Embora Costa (2011) considere que a identificação dos autores nessa região é inviabilizada pela ausência de documentos da terra, ao se analisar a fiscalização estadual, observa-se a existência de identificação por meio das bases dos CAR'S das propriedades. Tal documento também é um importante instrumento para a fiscalização ambiental por imagear a área aberta ilegalmente.
Na região do Tapajós, Novo Progresso foi o município com maior registro de auto de infração por desmatamento. A principal atividade econômica no município é a pecuária, estando presente tanto nas pequenas, quanto nas grandes propriedades (Lacerda, 2015). Nesse sentido, Lima \& Nóbrega (2009) apontam a pecuária, atividade impulsionada especialmente pela concessão de recursos financiados, como o principal vetor para o desmatamento no município. A atividade madeireira também tem um grande papel nesse contexto.

Ademais, Costa (2011) ressalta que existem explorações ilegais de madeira em todos os municípios do Oeste paraense. A maior concentração ocorre nas localidades cortadas pelas rodovias BR-230 e BR-163, em virtude da facilidade na logística de transporte do material. Assim, conforme o autor, os polos madeireiros nas regiões analisadas estão concentrados em Novo Progresso, Santarém e Itaituba (distrito de Moraes de Almeida). E se enquadram dentro dos seis municípios que mais apresentaram autos de infração lavrados em virtude de desmatamento no período estudado.

\subsubsection{Poluição e outros crimes}

Foram registradas 69 infrações referentes à poluição, perfazendo $11 \%$ do total de crimes analisados. A maior ocorrência foi no ano de 2013 $(n=33)$. Os maiores quantitativos de casos foram registrados nos municípios de Santarém $(n=18)$, Itaituba $(n=9)$, Monte Alegre $(n=7)$ e Alenquer $(n=5)$, ao passo que Aveiro, Faro e Jacareacanga não apresentaram registros (Figura 6).

Neste aspecto, o principal crime registrado foi o funcionamento de estabelecimentos, atividades, 
obras ou serviços sem licença ou em desacordo com a autorização concedida. Esse tipo de infração compreendeu 52 ocorrências, totalizando $75 \%$ do total de crimes relativos à poluição. Entre os municípios estudados, Santarém foi o que apresentou a maior quantidade de casos, com 12 registros, seguido de Monte Alegre, com 6 registros. A infração de armazenamento e transporte de substância tóxica ou perigosa, notadamente combustíveis, somou $10 \%$ dos casos, com 7 ocorrências. Já a execução de pesquisa/extração mineral sem licença representou 4\% dos casos, com 3 ocorrências (Figura 7).

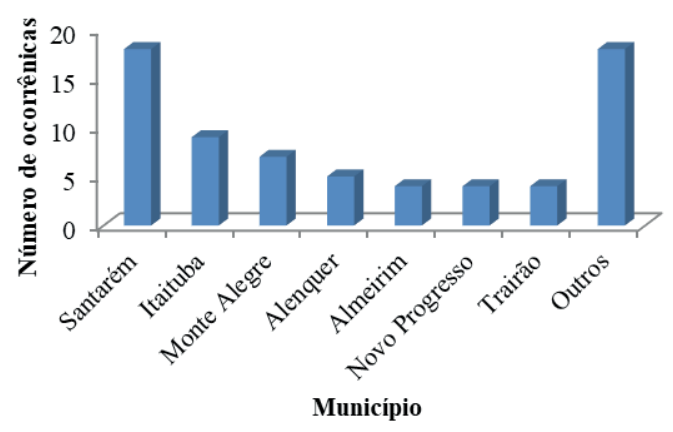

FIGURA 6 - Número de infrações referente à poluição e outros crimes por município, registradas no período de 2012 a 2015, nas regiões do Baixo Amazonas e Tapajós, Pará.

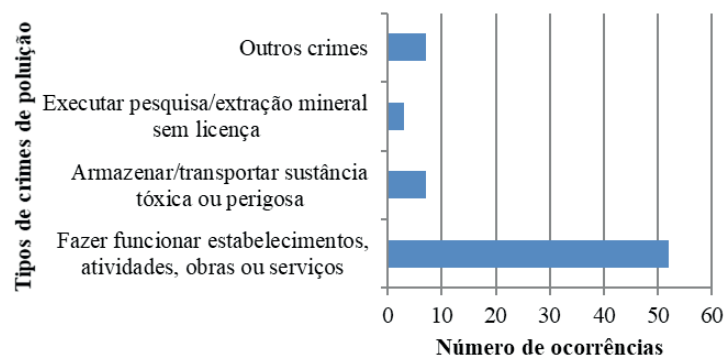

FIGURA 7 - Número e tipologias infracionais de poluição e outros crimes, registradas no período de 2012 a 2015, nas regiões do Baixo Amazonas e Tapajós, Pará.
A atividade de comércio varejista de combustíveis (posto de combustível) foi a que mais obteve registros $(n=19)$ em relação ao crime de funcionamento irregular ou ilegal de estabelecimentos, atividades, obras ou serviços. Os municípios de Santarém, Monte Alegre e Itaituba apresentaram 3 registros, cada. O ano de 2013 foi o que mais apresentou ocorrência desta tipologia infracional, com 12 registros. Já o funcionamento de serraria e porto fluvial para embarque e desembarque de passageiros obtiveram 6 e 3 registros, respectivamente. Atividades como movelaria, beneficiamento de madeira, fabricação de artefatos cerâmicos, fabricação de gelo, abate de bovinos e bubalinos, terraplanagem e pavimentação de vias, dentre outras, somaram 24 ocorrências (Figura 8).

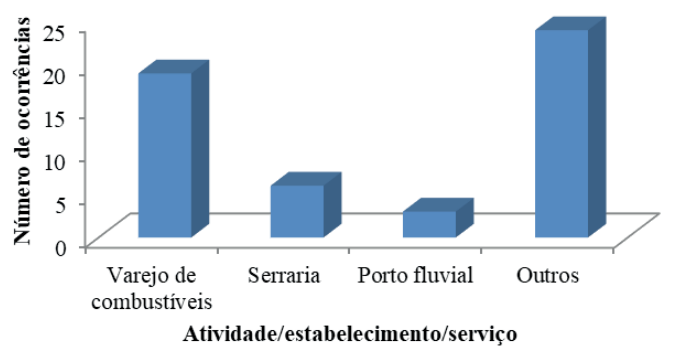

FIGURA 8 - Número de ocorrências de infrações por atividade, referente à tipologia de funcionamento irregular ou ilegal, no período de 2012 a 2015, nas regiões do Baixo Amazonas e Tapajós, Pará.

Ao contrário do esperado, a principal tipologia infracional de funcionamento irregular ou ilegal de estabelecimentos e atividades não tem relação com produtos e subprodutos advindos da flora, mas com derivados do petróleo. Isso reflete a importância da atividade de postos de combustíveis nas regiões em estudo. Esses empreendimentos geralmente estão localizados no perímetro urbano dos municípios, o que facilita a denúncia por parte da população e o 
acesso até os estabelecimentos em casos de vistorias pelas equipes de licenciamento e fiscalização do órgão ambiental.

Segundo Lorenzett \& Rossato (2010), os postos de combustíveis, por manipularem combustíveis fósseis, são atividades consideradas potencialmente poluidoras, podendo impactar o ambiente e contaminar o solo e lençol freático em função dos resíduos gerados. Como os postos prestam outros serviços além da comercialização do combustível, a exemplo da troca de óleo, uma gama de resíduos pode ser gerada: vapores e lodo tóxicos, flanelas contaminadas, óleo queimado, embalagens de lubrificantes, dentre outros, além da produção e emissão de efluentes líquidos. Além do potencial dano ambiental, riscos à segurança e saúde de funcionários e usuários também estão associados a este tipo de empreendimento.

Neste sentido, observa-se, de forma coerente, que os três municípios que mais apresentaram autos de infração pelo funcionamento irregular de postos de combustíveis são os que detinham as maiores frotas de veículos. A referência para essa análise considerou o mês de novembro de 2013, ano em que ocorreu o maior número de registros de infrações desta tipologia. De acordo com os dados do Departamento Nacional de Trânsito (DENATRAN, 2013), Santarém possuía uma frota de 73.445 veículos, Itaituba 26.103 e, Monte Alegre, 8.973 veículos.

Segundo Tavares (2016), a ocorrência de tais tipologias infracionais reflete a falta de educação ambiental dos empresários, tanto na ciência da necessidade e exigência do licenciamento ambiental, quanto da obrigação e importância em cumprir os termos da licença concedida. Há ainda empreendedores que, mesmo cientes da exigibilidade do licenciamento ambiental, preferem ignorá-la e/ou burlá-la e desempenhar a sua atividade de maneira ilegal, com a escusa de que a análise do procedimento é lenta e que o custo do processo de legalização da atividade é elevado, ou com a crença de que seu empreendimento dificilmente será fiscalizado.

A despeito disso, Lima (2013) afirma que o processo de licenciamento ambiental possui um lado burocrático envolvido que reflete a necessidade de se garantir ao máximo a preservação ambiental e expressa a preocupação em proteger os recursos ambientais. É preciso considerar que, de fato, não haverá desenvolvimento se o meio ambiente, a base de qualquer atividade econômica, for amplamente degradado, sendo, portanto, imperiosa a imposição de limites aos utilizadores dos recursos ambientais. No entanto, ainda segundo o mesmo autor, na visão de empreendedores e instituições econômicas, um processo burocrático e longo acaba se transformando em obstáculo ao desenvolvimento.

Neste contexto, é possível observar que a maioria dos crimes registrados na categoria de poluição advém da prática irregular da atividade. Logo, a constatação do ilícito ambiental pode ser tanto resultado do exercício regular da fiscalização e da análise de licenciamento de empreendimento já instalado e/ou operando em meio à solicitação de licença ou antes da concessão da autorização, como também de denúncias formalizadas. Neste último caso, conjectura-se essa possibilidade em virtude da visibilidade que a instalação e operação de um empreendimento e/ou atividade proporciona, especialmente no tocante a aspectos estruturais, de concorrência no mercado e passivos ambientais gerados. Porém, acredita-se que as tipologias infracionais arroladas na categoria de poluição e outros crimes ainda poderiam ser alvo de maiores denúncias por parte da população e de procedimentos fiscalizatórios pelo Estado. 
Em relação à fiscalização, uma das atividades que carecem desta prática é a mineração, a qual, embora possuindo importante destaque na região do Tapajós, obteve baixo registro de crime ambiental. Segundo o Ministério do Meio Ambiente - MMA (2006), a atividade minerária nas regiões estudadas concentra-se principalmente no município de Itaituba, representada por empresas de mineração e garimpos informais e formais. A informalidade é também observada na extração, em pequena escala, de areia, argila e brita, espalhadas por toda a região. Desse feito, como a informalidade de qualquer atividade tem implicações ambientais, sociais e econômicas incompatíveis com o desenvolvimento sustentável, é imperativa a adoção de medidas que visem o monitoramento das práticas e a implicação de punição, quando da sua execução irregular ou ilegal.

\subsubsection{Crimes contra a administração ambiental}

Os crimes contra a administração ambiental quantificaram 63 registros $(10 \%)$, sendo os municípios de Santarém $(n=25)$, Trairão $(n=6)$, Belterra $(n=5)$, Itaituba $(n=5)$, Novo Progresso $(n=5)$ e Prainha $(n=5)$ os que mais apresentaram ocorrências (Figura 9). Os municípios de Curuá, Faro, Jacareacanga, Juruti e Mojuí dos Campos não apresentaram registros de infrações contra a administração ambiental estadual.

Neste contexto das regiões estudadas, a principal infração ambiental identificada foi a prestação de informações totalmente ou parcialmente falsas e/ou enganosas aos sistemas oficiais de controle, com 33 registros (52\%). A maior parte - 12 regis- tros - ocorreu em Santarém. Em relação ao período de ocorrência desta tipologia, o maior número de registros ocorreu em 2014. A tipologia criminal de não atendimento das exigências legais reuniu 28 registros $(44 \%)$, se tornando o segundo crime mais recorrente - 12 dos casos também ocorridos no município de Santarém. Outros crimes registrados foram: apresentar estudo/relatório falso e obstar a ação do Poder Público no exercício da fiscalização, com 1 ocorrência, cada (Figura 10).

A prestação de informações falsas ou enganosas aos órgãos ambientais é danosa e lesiva porque compromete o controle, a conservação, defesa e me-

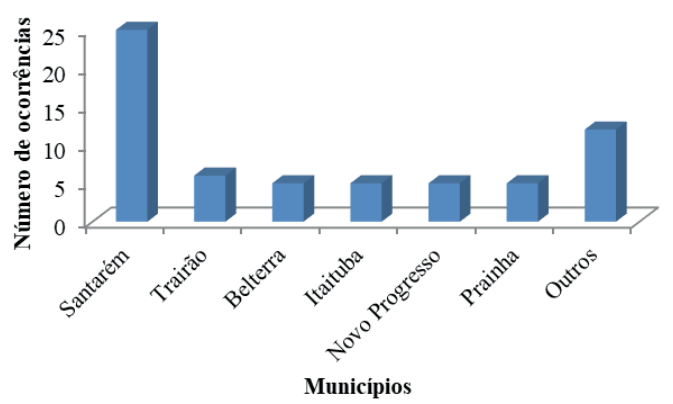

FIGURA 9 - Número de infrações contra a administração ambiental por município, registradas no período de 2012 a 2015, nas regiões do Baixo Amazonas e Tapajós, Pará.

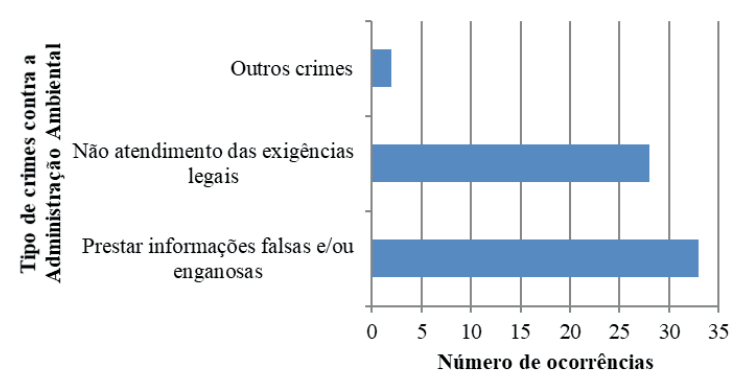

FIGURA 10 - Número e tipologias infracionais contra a administração ambiental, registradas no período de 2012 a 2015, nas regiões do Baixo Amazonas e Tapajós, Pará. 
1horia do ambiente. De forma geral, a prática busca auferir algum tipo de vantagem sobre determinada situação. Neste sentido, conforme Amado (2014), apresentar informações que não correspondam à verdade ou busquem induzir alguém a erro ferem a tutela da administração pública ambiental e o próprio meio ambiente. E, partindo-se do pressuposto que o meio ambiente é de uso comum, acrescenta-se, ainda, a lesão a toda uma coletividade como implicação de tal prática.

Diante disso, é importante destacar que a Resolução do Conselho Nacional do Meio AmbienteCONAMA n ${ }^{\circ} 237 / 1997$, em seu art. 11, parágrafo único, prevê que os estudos necessários ao licenciamento deverão ser realizados por profissionais legalmente habilitados. Neste sentido, considerando o autor supracitado, poderão consumar este crime os técnicos particulares, bem como outras pessoas não habilitadas que concorrerem para a sua consumação. Esses agentes estarão sujeitos a sanções administrativas, civis e penais.

Em relação à categoria da administração ambiental, observa-se que as tipologias criminais mais cometidas têm estreita relação com o licenciamento, refletindo a falta de compromisso do detentor da licença/autorização para com o órgão ambiental. Especificamente a prestação de informações parcialmente ou totalmente falsas e/ou enganosas por parte dos infratores ocorre especialmente por meio do Sistema de Comercialização e Transporte de Produtos Florestais (SISFLORA), que objetiva o controle da comercialização e o transporte de produtos florestais no Estado, sendo integrado ao Sistema de Cadastro de Consumidores de Produtos Florestais (CEPROF).

Neste sistema, dados obrigatórios de inserção pelo usuário, como volumetria de madeira, espécie e placa do veículo que realizará o transporte do produto florestal, são avaliados pelos servidores ambientais. Notadamente, como se trata de um sistema de inserção de dados, é possível que exista falha de digitação de informações pelo usuário. Assim, visando à constatação da ação fraudulenta ou errônea, há necessidade de realização de procedimento fiscalizatório in loco. E, por ser um sistema controlado pelo próprio órgão ambiental, deduz-se que a lavratura de autos relacionados a esta infração decorra principalmente da análise sistemática das informações realizada pelos operadores do sistema.

Desta forma, tal tipologia criminal está ligada principalmente aos crimes contra a flora. Essa foi a categoria que mais apresentou registros de autos nesta pesquisa, haja vista que envolve informações enganosas acerca da exploração, depósito, venda e consumo de produtos florestais. Igualmente, o município que apresentou maior número de autos lavrados relacionados à flora, Santarém, é o mesmo que lidera a constatação de ocorrência desta tipologia criminal. A existência de um Núcleo Regional da SEMAS em Santarém e a consequente facilidade de deslocamento até os empreendimentos deste município são outros fatores que podem explicar o desempenho do referido município no tocante a tipologia em análise.

\subsubsection{Crimes em outros dispositivos legais}

Infrações ambientais que não foram enquadradas nos artigos da Lei de Crimes Ambientais e seu decreto regulamentador, mas em outros dispositivos legais, totalizaram 34 ocorrências, correspondendo a $6 \%$ dos crimes totais. A maioria foi registrada em Santarém ( $\mathrm{n}=10)$, Itaituba $(\mathrm{n}=7)$ e Rurópolis $(\mathrm{n}=6)$. 
Com menor incidência, houve registros em Monte Alegre, Alenquer, Óbidos, Almeirim, Belterra, Oriximiná e Prainha (Figura 11).

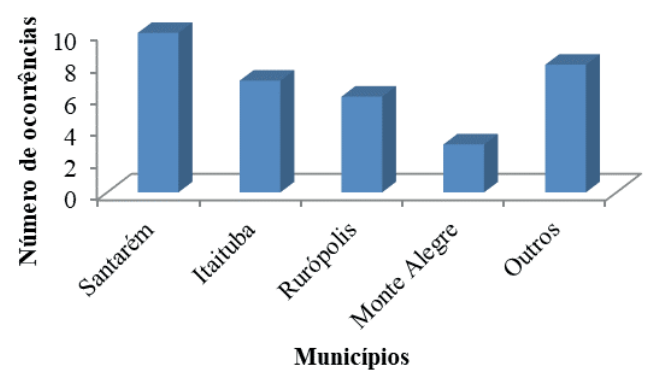

FIGURA 11 - Número de infrações previstas em outros dispositivos legais por município, registradas no período de 2012 a 2015, nas regiões do Baixo Amazonas e Tapajós, Pará.

Neste escopo, o tipo de infração mais cometida foi a extração/utilização de água subterrânea para consumo final, sem outorga de direito de uso ou em desacordo com a concessão obtida, totalizando 17 ocorrências (50\%), conforme Figura 12. O maior número de casos foi registrado em 2013 e nos municípios de Itaituba $(\mathrm{n}=6)$ e Santarém $(\mathrm{n}=5)$. Essa tipologia fora enquadrada na Lei Estadual $\mathrm{n}^{\mathrm{o}} 6.381 / 2001$, a Política Estadual de Recursos Hídricos.

A infração em razão do não cumprimento das etapas do licenciamento ambiental, tipologia criminal detectada durante o processo de solicitação de licenciamento da atividade junto à SEMAS, obteve 16 registros $(47 \%)$. Os casos ocorreram especialmente em Rurópolis ( $n=6)$ e em Santarém $(n=5)$, em 2014. Os empreendimentos que mais figuraram nesta tipologia foram os postos de combustíveis $(\mathrm{n}=7)$. Ademais, foi registrado um crime ambiental devido ao depósito de resíduos a céu aberto. Tais atos ilícitos foram enquadrados na Lei Estadual $n^{\circ}$
5887/1995, a Política Estadual de Meio Ambiente do Pará (Figura 12).

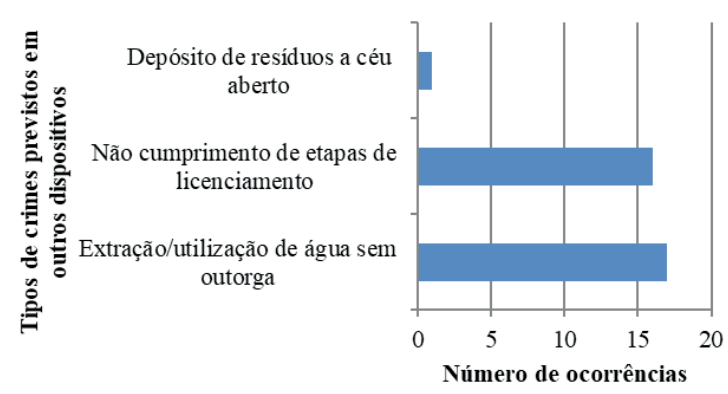

FIGURA 12 - Número e tipologias infracionais previstas em outros dispositivos legais, registradas no período de 2012 a 2015, nas regiões do Baixo Amazonas e Tapajós, Pará.

No órgão ambiental estadual, a outorga de água está relacionada, na maioria das vezes, ao processo de licenciamento ambiental, posto que a água faz parte do processo produtivo de grande parte das atividades econômicas, direta ou indiretamente. Assim, segundo Villar (2016), a maioria das extrações em condição irregular não visa a garantia dos direitos humanos ou a representação de interesses públicos, mas uma apropriação privada para fins produtivos que geram lucros a partir da dilapidação de um patrimônio comum.

É válido mencionar que as solicitações de licença ambiental e outorga de água são objeto de processos distintos na SEMAS. Desta forma, o crime ambiental de extrair e/ou utilizar água sem outorga pode estar relacionado ao funcionamento irregular de atividades. Isso porque, se um empreendimento não obteve licença ambiental, certamente também não detém outorga válida ou dispensa de outorga. Assim, fazer funcionar um estabelecimento sem licença e utilizar água sem outorga ou em 
desacordo com a autorização obtida pode gerar ao infrator dois autos de infração diferentes. Por outro lado, operar empreendimento com licença válida, mas sem outorga de água, com outorga vencida ou, ainda, com ela em desacordo, ou vice-versa, gera ao infrator apenas um auto de infração.

Neste sentido, observando os resultados anteriores atinentes à categoria de poluição, nota-se que o número de autos lavrados em função da existência de empreendimentos sem licença ou com ela em desacordo é superior ao da tipologia infracional de uso de água sem outorga ou com ela em desacordo. Vislumbra-se, então, que a maioria dos empreendimentos detinha outorga válida (ou dispensa), mas contrariaram as permissões concedidas em licença ambiental, operavam com licença vencida ou sem licença. É possível ainda que grande parte dos empreendimentos constatados em condição irregular ou ilegal utilizasse água da rede pública de abastecimento, condição em que não há necessidade de solicitação de outorga (ou dispensa) de água ao órgão ambiental estadual.

É preciso considerar, também, que no funcionamento de postos de combustíveis- os empreendimentos que mais figuraram operando sem licença ou contrariando suas disposições - geralmente não se realiza a captação de água subterrânea. $\mathrm{Na}$ maioria das vezes, a água é proveniente do serviço público de distribuição. E, retomando os resultados da tipologia de funcionamento irregular de estabelecimentos, Santarém também foi o município em que mais se registrou o crime de utilização de água sem outorga ou com ela em desacordo.

\subsubsection{Crimes contra a fauna}

Observou-se um total de 21 infrações (4\%) contra a fauna no período em estudo, ocorridas em apenas 5 municípios, a saber: Jacareacanga $(\mathrm{n}=7)$, Santarém ( $\mathrm{n}=6)$, Monte Alegre $(\mathrm{n}=4)$, Óbidos $(\mathrm{n}=2)$ e Curuá ( $\mathrm{n}=2$ ) (Figura 13).

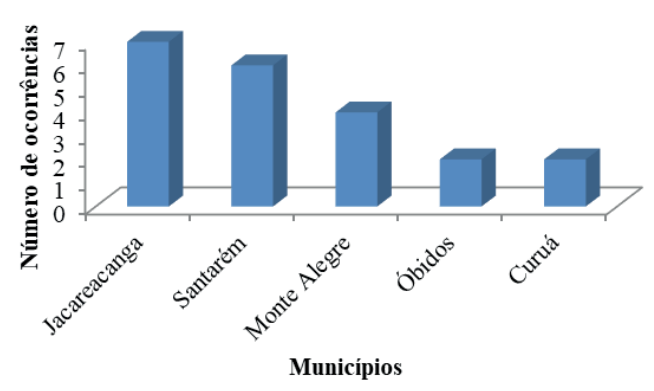

FIGURA 13 - Número de infrações contra a fauna por município, registradas no período de 2012 a 2015, nas regiões do Baixo Amazonas e Tapajós, Pará.

Considerando o recorte analisado, os tipos de crimes contra a fauna mostraram-se bastante diversificados. Armazenamento irregular de pescado, depósito/transporte de ovos de répteis, pesca sem prévio cadastro/permissão e transporte de peixe em período de defeso e sem declaração de estoque foram os crimes mais cometidos, com 3 registros cada, com ocorrência principalmente em Jacareacanga (Figura 14). $\mathrm{O}$ ano de 2012 foi o período em que esses tipos de infrações foram mais registrados.

As tipologias infracionais contra a fauna também costumam ser bastante diversas em outras regiões do Norte do país. Em estudos realizados no município acreano de Cruzeiro do Sul e nos municípios amazonenses de Guajará e Ipixuna, Queiroz et al. (2013) observaram a ocorrência de 10 tipos de 
infrações. O principal caso foi o depósito de carne de animais silvestres, que perfez $23,2 \%$ do total analisado, de 2003 a 2009. Ao estudarem apenas a fauna silvestre no estado do Amapá, no período de 2005 a 2009, Dias Júnior et al. (2014) observaram que a posse de animais em cativeiro e o transporte de carne de animais silvestres foram os crimes mais cometidos. Na presente pesquisa, observou-se que as tipologias infracionais envolvendo os pescados foram as mais recorrentes.

O baixo número de autos de infração contra a fauna lavrados pela fiscalização estadual pode ser explicado pela pequena quantidade de denúncias relativas à fauna e à pesca ilegais. Além disso, mesmo quando ocorre denúncia ou fiscalização sistemática, o flagrante e a consequente constatação do ilícito

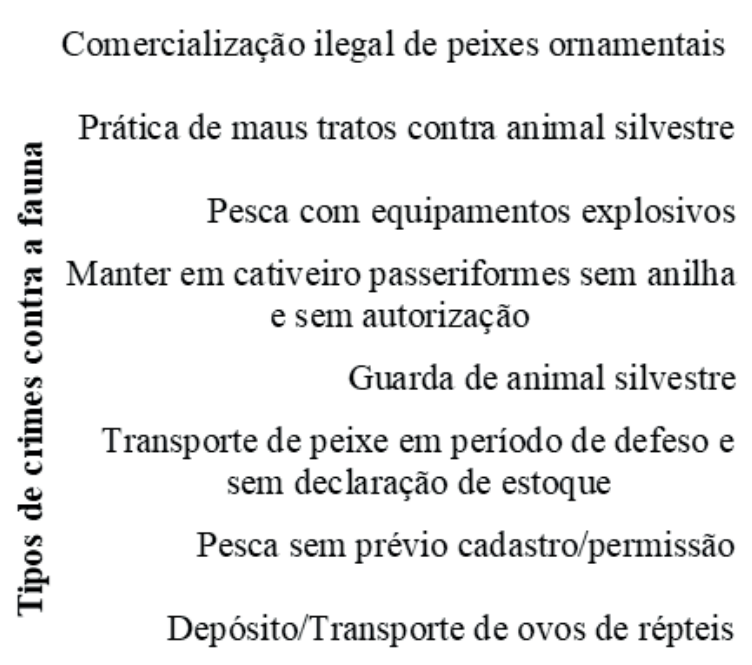

Armazenamento irregular de pescado ambiental por parte dos agentes ambientais é difícil. Isso acontece por causa da facilidade no transporte de pescados e animais silvestres vivos ou mortos. Essa situação não ocorre, por exemplo, com toras de madeiras. Assim, considerando as dimensões das áreas municipais das regiões estudadas e o efetivo deslocamento e chegada da equipe de fiscalização ao local da suposta infração, vislumbra-se a existência de tempo suficiente para que os infratores ocultem os espécimes ilegais ou os soltem no ambiente.

Nas regiões estudadas, é notória a maior atuação do IBAMA na apuração de crimes dessa natureza. A autarquia federal, por meio de operações sistemáticas e ações rotineiras, tem demonstrado forte desempenho na apreensão de espécimes ilegais da fauna e aplicação de multa aos infratores.

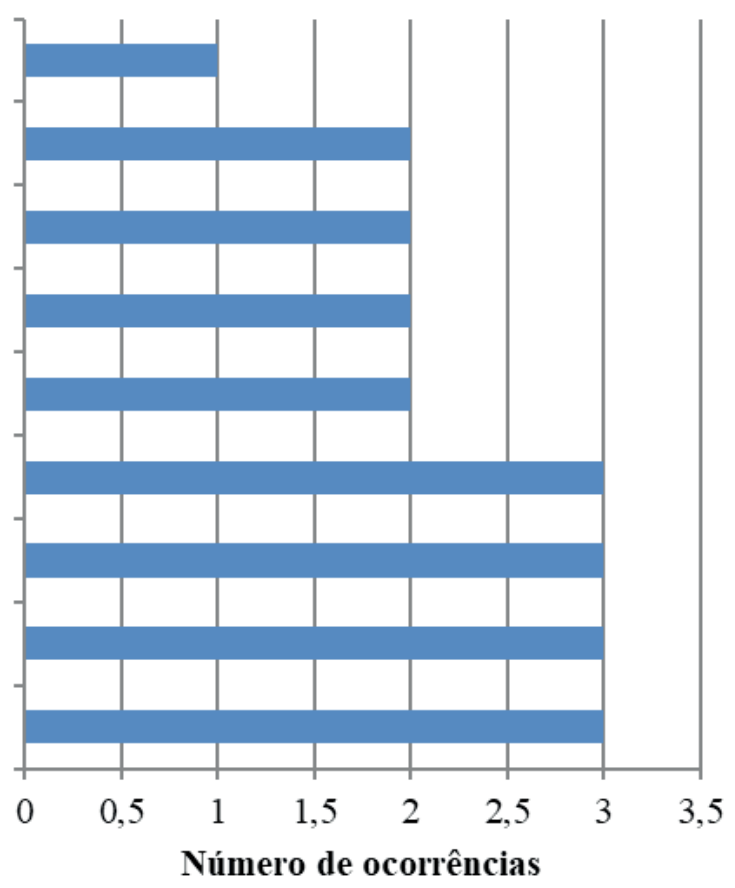

FIGURA 14 - Número e tipologias infracionais contra a fauna, registradas no período de 2012 a 2015, nas regiões Baixo Amazonas e Tapajós, Pará. 
Ao mesmo tempo, é preciso considerar que alguns órgãos ambientais municipais, a exemplo das secretarias municipais de meio ambiente de Santarém, Itaituba, Óbidos e Monte Alegre, exercem a gestão ambiental local de forma plena ou parcial. Sendo assim, a competência destes órgãos abarca o exercício da fiscalização ambiental municipal. Também cumpre destacar que, em operações fiscalizatórias conjuntas entre os órgãos ambientais, apenas um dos órgãos instaura o procedimento administrativo em desfavor dos autuados. Desta forma, o auto de infração é incorporado apenas às estatísticas do órgão ambiental que o lavrou.

No entanto, é possível que haja um aumento de registros de crimes contra a fauna nos próximos anos pelo órgão ambiental estadual. Em abril de 2013, o IBAMA, por meio de acordos de cooperação técnica, repassou à SEMAS a gestão e operacionalização do Sistema Nacional de Gestão de Fauna (SisFauna), para empreendimentos e atividades relacionadas ao uso e manejo da fauna silvestre, e do Sistema de Cadastro de Criadores Amadoristas de Passeriformes (SisPass), para o controle das operações de manejo dos criadores amadoristas de passeriformes. Com isso, após o período de adaptação aos novos sistemas, a fiscalização ambiental estadual poderá ser mais efetiva no tocante à proteção da fauna. Ainda assim, para que as infrações possam ser constatadas, há a necessidade de aumentar o número de fiscais ambientais estaduais, visando ao atendimento de tais demandas.

\section{Considerações finais}

A potencialização dos interesses privados na exploração dos recursos perfaz uma grande ameaça à conservação da biodiversidade amazônica, ao passo que também estimula a ocorrência de crimes ambientais. Neste contexto, o desmatamento, considerado um dos maiores problemas ambientais da atualidade, é também o principal crime ambiental constatado nas regiões paraenses estudadas, mantendo a sociedade em um ciclo vicioso de destruição ambiental. Ainda que as causas do desmatamento mudem invariavelmente à proporção que surgem novas pressões, a pecuária, a agricultura e a exploração madeireira estão entre as atividades que convergem para a eliminação direta da floresta - dinâmica que esta presente na realidade das regiões estudadas.

Mesmo as áreas protegidas legalmente pelo Código Florestal, reserva legal e área de preservação permanente, espaços instituídos com vistas à conservação da biodiversidade e à contenção do desmatamento, são alvo do desrespeito às leis de proteção ambiental e acabam sendo ameaçadas e destruídas por essa atividade. Por outro lado, identifica-se a importância da estrutura organizacional do ente fiscalizador, da adoção de ferramentas de monitoramento ambiental e da formação de parcerias institucionais como suporte às normas protetivas $\mathrm{e}$ repressivas ambientais, auxiliando na identificação do ilícito ambiental e posterior responsabilização do infrator. A constatação do desmatamento depende, portanto, de ações estratégicas de monitoramento, fiscalização e controle, especialmente em áreas expostas a ameaças antrópicas.

Embora variados instrumentos possam ser adotados para o monitoramento do desmatamento, igual atenção deve ser dada, também, aos demais crimes ambientais não identificados ou apurados em menor quantidade nas regiões estudadas. Tais situações podem levar a um incorreto entendimento de que não há ocorrência de crimes ambientais ou 
que eles não ocorrem de maneira intensa na realidade destes locais. Esse tipo de contexto é oportuno para que os infratores possam concretizar crimes, baseados na certeza que dificilmente serão autuados e repreendidos legalmente. Ademais, tão importante quanto os esforços fiscalizatórios empreendidos na constatação dos ilícitos ambientais é saber como emanam os motivos para sua ocorrência. Portanto, reconhecer e controlar as atividades que originam crimes praticados no território é indubitavelmente necessário para a formulação de estratégias que coíbam a destruição do ecossistema amazônico.

Neste sentido, o estudo também permitiu visualizar a distribuição e concentração dos crimes ambientais nas regiões estudadas. O município de Santarém foi o que apresentou maior número de autos de infração lavrados, liderando quatro das cinco categorias registradas. Por Santarém deter a maior população entre os municípios estudados e, considerando que as pressões ambientais são ocasionadas principalmente pela ação antrópica, é presumível que exista nesta área maior tendência na ocupação do espaço por atividades produtivas e econômicas. Isso concorre para a alteração do ambiente e a consequente existência de ilícitos ambientais. Atrelada a isso, a desconcentração do órgão ambiental em Santarém sugere uma maior facilidade na execução das ações fiscalizatórias neste município.

Ao mesmo tempo, a baixa quantidade de autos de infração lavrados na maioria dos municípios não significa que ilícitos ambientais não ocorram nesses locais. Os resultados indicam, então, que, além das características socioeconômicas, fatores logísticos associados ao órgão fiscalizador podem influenciar a constatação dos crimes ambientais nos municípios mais afastados das bases adminis- trativas do órgão. Tal situação também dificulta o contato da população com o órgão ambiental, em caso de fornecimento de denúncias. Neste cotejo, é oportuna a realização de outros estudos para testar tais hipóteses. Em todo o caso, é fato que a fiscalização ambiental deve ser planejada de maneira a alcançar e ser mais atuante e presente em todos os municípios.

De maneira geral, mais do que indicar quais os maiores crimes ambientais registrados nas duas regiões, o estudo reflete o comportamento da sociedade no que diz respeito à prática de condutas lesivas ao ambiente e que precisam ser combatidas. Isso é apresentado ao passo que também afirma ao Estado dois importantes e urgentes campos de atuação. São eles: a prevenção dos crimes por meio da educação ambiental da população, como forma de preveni-los; e a punição aos infratores, como forma de repreender e disciplinar quem causa danos ao ambiente e à sociedade

\section{Referências}

Amado, F. A. D. T. Direito ambiental esquematizado. Rio de Janeiro: Forense; São Paulo: MÉTODO, 5.ed., 2014.

Brasil. Constituição da República Federativa do Brasil, de 5 de outubro de 1988. São Paulo: Atlas, 11. ed., 1988.

Copola, G. A lei dos crimes ambientais comentada artigo por artigo: jurisprudência sobre a matéria. Belo Horizonte: Fórum, 2. ed., 2012.

Costa, V. O. B. Dinâmica do desmatamento na região Oeste do Pará. Curitiba, Monografia (Especialização em Gestão Florestal) - UFPR, 2011.

Costa, T. C. S. Urbanização e diversidade sócio-espacial no Baixo Amazonas: Santarém e a produção do urbano-regional. Ensaios de Geografia, 4, 71-85, 2015 a. 
Costa, S. M. G. Sojicultura e mercado de terras na Amazônia. Revista de Politicas Públicas, 19, 173-185, 2015 b.

Dalgo, L. S. C.; Suhett, L. S. M. Uma análise legal e econômica do desmatamento na Amazônia. Rio de Janeiro, TCC (Graduação em Engenharia Ambiental) - UFRJ, 2009.

Dias Júnior, M. B. F.; Cunha, H. F. A.; Dias, T. C. A. C. Caracterização das apreensões de fauna silvestre no estado do Amapá, Amazônia oriental, Brasil. Biota Amazônica, 4, 65-73, 2014.

DENATRAN - Departamento Nacional de Trânsito. Frota municipal de veículos em novembro/2013, 2013.

Fonseca, A. M. T.; Valente, L. M.; Lopes, M. C. Diagnóstico dos crimes contra a flora a partir das ações impetradas pelo Ministério Público Federal. Revista Eletrônica do Curso de Direito da UFSM, 8, 122-140, 2013.

IBGE - Instituto Brasileiro de Geografia e Estatística. Estimativas da população residente nos municípios brasileiros com data de referência em $1^{\circ}$ julho de 2015, 2015a.

IBGE - Instituto Brasileiro de Geografia e Estatística. Área territorial municipal oficial, 2015b.

IPHAN - Instituto do Patrimônio Histórico e Artístico Nacional. Lista de bens tombados e processos de tombamento em andamento (1938-2015), 2015.

Lacerda, R. B. Fazer movimentos: mobilidade, família e estado no Sudoeste Paraense. Rio de Janeiro, Dissertação (Mestrado em Sociologia e Antropologia) - URRJ, 2015.

Lima, A.; Nobrega, B. Indicadores socioeconômicos e espaciais dos municípios prioritários para o controle do desmatamento no Estado do Pará. [s.1.]: IPAM, 2009.

Lima, L. I. A. O licenciamento ambiental como instrumento da Política Ambiental: o caso da Linha de Transmissão Corumbá IV- Santa Maria. Brasília, TCC (Graduação em Geografia) - UnB, 2013.

Lorenzett, D. B.; Rossato, M. V. A gestão de resíduos em postos de abastecimento de combustível. Revista Gestão Industrial, 6, 110-125, 2010.

Milaré, E. Direito do Ambiente: a gestão ambiental em foco. São Paulo: Revista dos Tribunais, 7. ed., 2011.
MMA - Ministério do Meio Ambiente. Plano de ação (2062007): DFS BR-163. Brasília, 2006.

Motta, D. M.; Pêgo, B. Licenciamento ambiental para $o$ desenvolvimento urbano: avaliação de instrumentos e procedimentos. Rio de Janeiro: Ipea, 2013.

Munhoz, C. S. Eficácia das políticas públicas de desmatamento na Amazônia Legal: Governo Fernando Henrique Cardoso e Luiz Inácio. Brasília, TCC (Graduação em Direito) - Centro Universitário de Brasília, 2011.

Ortega, G. P.; Queiroz, A. M.; Valente, R. A. S.; Zumba Júnior, F. P. Crimes ambientais cometidos contra a flora no município de Cruzeiro do Sul-Acre de 2003 a 2010. Enciclopédia Biosfera, 8, 1113-1122, 2012.

Queiroz, A. M.; Ortega, G. P.; Valente, R. A. S.; Zumba Júnior, F. P. Z. Crimes contra a fauna registrados no município de Cruzeiro do Sul- Acre, Guajará e Ipixuna- Amazonas no período de 2003 a 2009. Enciclopédia Biosfera, 9, 21-54, 2013.

Reydon, B. P. O desmatamento da floresta amazônica: causas e soluções. Política Ambiental, 1, 143-155, 2011.

Santilli, J. Tutela Penal do Meio Ambiente. In: Rocha, J. C. C.; Henriques Filho, T. H. P.; Cazetta, U. (Orgs.). Politica Nacional do Meio ambiente: 25 anos da Lei. São Paulo: Del Rey, p. 347- 384, 2007.

Schmitt, J. Crime sem castigo: a efetividade da fiscalização ambiental para o controle do desmatamento ilegal na Amazônia. Brasília, Tese (Doutorado em Desenvolvimento Sustentável) - UnB, 2015.

Simoni, J.; Lindoso, D.; Debortoli, N.; Ibiapina, I.; Eidt, G. Instituições e políticas públicas em territórios da Amazônia: desafios para a capacidade adaptativa e redução de vulnerabilidades. In: Anais do VI Encontro Nacional da Anppas. Belém, 18 de set., 2012.

Tavares, R. A. Distribuição dos autos de infrações ambientais lavrados pela fiscalização estadual na Paraíba no ano de 2014. Campina Grande, TCC (Graduação em Engenharia Sanitária e Ambiental) - Universidade Federal da Paraíba, 2016.

Tedardi, M. S. Proteção ao meio ambiente: considerações acerca dos aspectos penais. Revista Fapciência, 5, 37-54, 2009. 
Uhr, J. G. Z.; Uhr, D. A. P. Infrações ambientais e a reputa- Villar, P. C. As águas subterrâneas e o direito à agua em um ção do regulador: análise em dados de painel para o Brasil. contexto de crise. Ambiente \& Sociedade, 29, 83-102, 2016. Estudos Econômicos, 44, 69-103, 2014. 